\title{
Analyze the Effect of Aconex System on Project Administration Process
}

\author{
$1^{\text {st }}$ Andri D Prasetyo \\ Faculty of Administrative Sciences \\ Universitas Indonesia \\ Jakarta, Indonesia \\ andri.dian@ui.ac.id
}

\author{
$2^{\text {nd }}$ Bernardus Y Nugroho \\ Faculty of Administrative Sciences \\ Universitas Indonesia \\ Jakarta, Indonesia
}

\author{
$3^{\text {rd }}$ Ferdinand D Saragih \\ Faculty of Administrative Sciences \\ Universitas Indonesia \\ Jakarta, Indonesia
}

\begin{abstract}
The purpose of this research is to examine the effects of aconex system and investigating the key determinants of the administration process. We proposed a conceptual framework based on the unified theory of acceptance and use of technology (UTAUT) aims to explain user intentions to use an information system and subsequent usage behavior. A total of 267 valid questionnaires were collected from project staff users through an online survey. Data were analyzed using structural equation modeling (SEM) techniques. The result shows that four key constructs of UTAUT have a significant positive impact on the administration process. We also provide a detailed discussion about these findings and the theoretical and practical implications of the research
\end{abstract}

Keywords-Aconex System, UTAUT, Administration Process, Information System

\section{INTRODUCTION}

According to data compiled by Bank Indonesia in 2018, it is known that the Performance category of the Construction business sector continues to increase and significantly contributes to the overall economic performance. Referring to the classification of Gross Domestic Product (GDP) in the base year 2010, the Construction business category includes 1) General construction activities of various kinds of buildings, including new construction, building repairs, building additions, and renovations, as well as the construction of prefabricated buildings or structures on-site and temporary construction; 2) General construction activities of civil buildings, both new buildings, building repairs, building additions and building changes, construction of prefabricated buildings/structures at a temporary location and construction; 3) Special construction activities (related to specialized expertise) on one aspect of the structure that requires equipment or special skills including plumbing installation, heating/air conditioning, alarm systems, electrical systems, etc [1].

Based on Gross Domestic Product (GDP) data, in the last seven years (2011 - 2017), the Construction business category has a relatively large share of Indonesia's GDP structure, which is $9.82 \%$ or ranks 4 th in the structure of the Indonesian economy. The share of the construction business category tends to increase. In the first quarter of
2018, the share of the Construction business category to the national economy was $10.49 \%$, higher than the average share during the 2011 - 2017 period [1]

One part of the activities carried out by construction companies is project management, according to the Project Management Institute in the PMBOK Guide (Project Management Institute 2004, p.5) project management is the application of knowledge, skills, tools, and techniques to project activities to meet the needs Project Management is carried out through the application and integration of project management processes. The process is project initiation, project planning, project execution, project monitoring and control, and the final results. On the other hand, with the increasing scale and number of existing projects, accompanied by limited resources, facilities, time and energy, monitoring, and controlling activities in a project become increasingly complex and complicated. For that, we need a tool that can help a Project Leader monitor and control his projects dynamically and actually [2].

In its activities, companies, including construction companies, are still facing difficulties in the function of their file administration activities. Companies activities related to photos, drawings, and documents related to the project design and construction process, where information retrieval ability sometimes encounters differences. Hence, documents become uncontrolled due to the process. which is carried out using only a simple manual process, so the problem is the output relates to the saving of project drawings, work documents, and the results of the inspection process of the construction process itself [3].

Many companies outsource activities that are not considered to be the core of their business. These activities also apply to construction companies who want to use tools such as construction software. Construction companies do not want to be bothered with IT procurement, management, and maintenance issues that are not a core competency for them. For this reason, a third party is needed who can provide services to provide tools that can help monitor and control their projects. Therefore, the company uses a documentation system called the Aconex System. 
This study aims to examine the aconex system and investigate the factors that influence behavior in using the system from the administrative process.

\section{THEORETICAL FRAMEWORK}

This study refers to several theories that serve as a reference which includes theories regarding performance expectancy, effort expectancy, social influence, facilitating conditions, behavioral intention, and use behavior [4].

A. Performance Expectancy

Defined as an individual's level of trust in the extent to which the use of the system will help users to be able to improve performance in their work. This belief can also arise because of the influence of the work environment [4].

\section{B. Effort Expectancy}

Effort Expectancy is the level of convenience associated with the use of systems that will be able to reduce the effort (energy and time) of individuals in doing their work. By using a system, work can be done more quickly. This advantage will affect someone in completing each job [4].

\section{Social Influence}

They are interpreted as the level where an individual considers that other people influence to convince himself that he must use a new system. An individual will dare to decide to use the system if he gets certainty that using the system to complete his work does not violate the subjective norms that apply in society [4].

\section{Facilitating Conditions}

Is the level of confidence of an individual in the availability of technical and organizational infrastructure to support the use of the system. Facilitating conditions are defined as the extent to which a person believes that factors such as the availability of devices, knowledge, guidance, and others in his social group are available to support the use of a system [4].

\section{E. Behavioral Intention}

It is defined as the level of desire or intention of users to use the system continuously. A person will be interested in using new information technology if the user believes that using information technology will improve its performance. People also by using information technology that can be done quickly and get the influence of the surrounding environment in using information technology. Utilization interest will have a significant positive effect on technology use [4].

\section{F. Use Behavior}

Defined as the intensity and or frequency of users using information technology. Information technology usage behavior is very dependent on user evaluation of the system. Users will feel comfortable and will continue to use the system if the system provides benefits or benefits that have a positive effect on their work [4].

Thus the above literature leads us to formulate the following research hypotheses:

1. H1: There is a positive effect of Performance Expectancy and Behavioral Intention in using the Aconex system

2. H2: There is a positive effect of Effort Expectancy and Behavioral Intention on the use of the Aconex system

3. H3: There is a positive effect of Social Influence and Behavioral Intention on the use of the Aconex system

4. H4: There is a positive effect of Facilitating Condition and Use Behavior on Aconex systems

5. H5: There is a positive effect of Behavioral Intention and Use Behavior in the use of the Aconex system

\section{RESEARCH METHOD}

A. Research Approach

Descriptive quantitative was used in research design to test the research hypothesis and explain the relationship between the variables studied. In this study, the data collection process was only done once where the data was taken from a group of respondents in a target population, so this study used a single cross-sectional design [5].

B. Research Data Collection \& Sources

The data in the study were divided into 2 , namely primary data and secondary data. Primary data were obtained from the online survey through Google Forms on period April-June 2020. Secondary data are obtained from the study of literature, both from internal documents, previous research, scientific articles, books, the internet, and data from related parties.

C. Data Analysis Method

Data collected from the results of the questionnaire were then processed using the Partial Least Square Structural Equation Modeling (PLS-SEM) method.

\section{RESULT}

\section{A. Respondent's Demography}

From the conducted surveys, there are several demography aspects which can be described, including the gender of respondence, age, and their job description, as mentioned in this bellow table:

TABLE I. DEMOGRAPHICS OF RESPONDENTS

\begin{tabular}{|l|c|c|c|}
\hline \multicolumn{2}{|c|}{ Category } & $\begin{array}{c}\text { Qty } \\
\text { (Respondents) }\end{array}$ & $(\boldsymbol{\%})$ \\
\hline Gender & - Male & 236 & $88,4 \%$ \\
& - Female & 31 & $11,6 \%$ \\
\hline Age & $-18-25$ & 38 & $14,5 \%$ \\
& $-26-35$ & 150 & $56,4 \%$ \\
& $-36-45$ & 65 & $24,5 \%$ \\
& $->46$ & 14 & $4,4 \%$ \\
\hline
\end{tabular}




\begin{tabular}{|l|c|c|c|}
\hline \multicolumn{2}{|c|}{ Category } & $\begin{array}{c}\text { Qty } \\
\text { (Respondents) }\end{array}$ & $(\boldsymbol{\%})$ \\
\hline Job Description & - Document Control & 32 & $12 \%$ \\
& - Administration & 24 & $9 \%$ \\
& - Architect & 75 & $28,1 \%$ \\
& - Engineer & 68 & $25,4 \%$ \\
& - Supervisor & 12 & $46 \%$ \\
& - Other & & \\
\hline
\end{tabular}

Source: Research Data Analysis (2020)

Majority of the participants were male staffs totaling to 236 participants $(88.4 \%)$ while female participants were 31 $(11,6 \%)$ because of the construction project was majority male staff, Productive age was top of the other $(56,4 \%)$ and aconex systems with a vulnerable age of 46 , and above, not many people use computers for their daily works $(4,4 \%)$, Among the participants, most job description in top three in construction project was Architech $(28,1 \%)$, Engineer (25,4\%), and Site Supervisor (21\%)

\section{B. Reliability Coefficients of Constructs}

In addition to testing the construct validity, researchers also conducted a construct reliability test measured using two criteria, namely Composite Reliability and Cronbach Alpha (Ghozali, 2011). A latent variable must have a Cronbach's Alpha value of more than 0.7 or Composite Reliability of more than 0.7 to meet reliability [6].

According to Chin [7], Composite Reliability is a closer and more accurate approximation so that the reliability evaluation is done by looking at the value of Composite Reliability.

From Table 2 below, it can be seen that all constructs have composite reliability values above 0.7 so that all constructs can be declared reliable.

TABLE II. RELIABILITY CRONBACH' ALPHA, COMPOSITE RELIABILITY, AVE

\begin{tabular}{|l|c|c|c|}
\hline Description & $\begin{array}{c}\text { Cronbach' } \\
\text { Alpha }\end{array}$ & $\begin{array}{l}\text { Composite } \\
\text { Reliability }\end{array}$ & $\begin{array}{l}\text { Average } \\
\text { Variance } \\
\text { Extracted } \\
\text { (AVE) }\end{array}$ \\
\hline - Behavioral Intention & 0,928 & 0,954 & 0,874 \\
- Effort Expectancy & 0.830 & 0.879 & 0.593 \\
- Facilitating Condition & 0,802 & 0,882 & 0,714 \\
- Performance Expectancy & 0,925 & 0,952 & 0,870 \\
- Social Influence & 0,883 & 0,928 & 0,810 \\
- Use Behavior & 1.000 & 1.000 & \\
\hline
\end{tabular}

Source: Research Data Analysis (2020)

\section{Hypotheses Testing and Discussion}

Hypothesis testing is done by looking at the value of the t-value at each path coefficient. We employ the bootstrapping resampling technique to find out the significance value of the path coefficient. The hypothesis given is a type of one-tailed test, so the expected t-value is> 1,282 to be stated that the hypothesis is accepted. Table 3 summarizes the results of the structural evaluation model based on the value of the path coefficient and t-value.

TABLE III. RESULT OF PATH COEFFICIENT BOOTSTRAPPING WITH SMART-PLS

\begin{tabular}{|c|c|c|c|c|c|c|}
\hline & $\begin{array}{c}\text { Original } \\
\text { Sample }(0)\end{array}$ & $\begin{array}{c}\text { Sample } \\
\text { Mean }\end{array}$ & $\begin{array}{l}\text { Standard } \\
\text { Deviation } \\
(\text { STDEV) }\end{array}$ & $\begin{array}{c}\text { T Statistics } \\
\text { (|O/STDEV| } \\
\text { ) }\end{array}$ & P Values & Results \\
\hline $\begin{array}{l}\text { Behavioral } \\
\text { Intention -> Use } \\
\text { Behavior Effort } \\
\text { Expectancy -> } \\
\text { Behavioral } \\
\text { Intention } \\
\text { Facilitating } \\
\text { Condition -> Use } \\
\text { Behavior } \\
\text { Performance } \\
\text { Expectancy -> } \\
\text { Behavioral } \\
\text { Intention } \\
\text { Social Influence -> } \\
\text { Behavioral } \\
\text { Intention }\end{array}$ & 0.454 & 0.456 & 0.071 & 2.021 & 0.000 & Accepted \\
\hline
\end{tabular}

Source: Research Data Analysis (2020) 


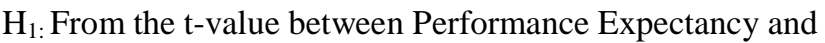
Behavioral Intention, it can be concluded that this hypothesis is accepted because it has a value of 2.127 , which is above 1.282. According to A C Obiennu [8], this result means that user performance expectations influence on the interest in system utilization. This relationship condition shows that the user's trust in using the Aconex system makes the user improve their performance.

$\mathrm{H}_{2:}$ From the t-value between Effort Expectancy and Behavioral Intention, it can be concluded that this hypothesis is accepted because it has a value of 2,021, which is above 1,282. Previous research conducted by M K Ghairaibeh [9], All members agreed that the process of mobile banking services is easy to remember, especially through accumulated usage. They, too, agreed that performing banking transactions via smartphones does not take much time. This result means that the business expectations of the user influence the utilization interest. This condition shows that the ease of use of the Aconex system allows users to use the Aconex system easily.

$\mathrm{H}_{3}$ : From the t-value between Social Influence and Behavioral Intention, it can be concluded that this hypothesis is accepted because it has a value of 3,451 , which is above 1,282. Previous research conducted by M K Ghairaibeh [9], the members agreed that mobile banking services are a status symbol in the community. This means that Social Influence influences interest in the environment. This condition shows that the social factors that exist in the work environment make users access aconex system.

$\mathrm{H}_{4}$ : From the t-value between Facilitating Condition and Use Behavior, it can be concluded that this hypothesis is accepted because it has a value of 7,006, which is above 1,282 , it had the highest impact of the independent variable. This result means that Facilitating Condition influences usage behavior. According to A C Obiennu [8], Facilitating Condition had the $2^{\text {nd }}$ highest of his research, this condition indicates that the facility condition factor in the Aconex software and hardware system is capable of doing its work, and also company give the best facility to the staff for using of aconex system

$\mathrm{H}_{5}$ : From the t-value between Behavioral Intention and Use Behavior, it can be concluded that this hypothesis is accepted because it has a value of 1,516, which is above 1,282. According to I G N Sedana [10], this finding is consistent with the basic concept of user acceptance models. Namely, the intention to use information technology will affect the actual use of information technology. This means that Behavioral Intention has a positive influence on Use Behavior. This condition shows that the intention and desire of the user to use the aconex system is already at the level of comfort for its use, the user feels he has benefited as well as the benefits that have a positive effect on his work.

\section{CONCLUSION AND FUTURE RECOMMENDATION}

Results of research show UTAUT is a model that can be used for aconex system, with PLS-SEM respondents have high accepted results of performance expectancy, effort expectancy, social influence, facilitating condition, and behavioral intention. In this construction project facility used for running aconex system is generously suitable according to the result that brings the facilitating condition become the highest hypothesis result, the results of previous studies also suggest that facilitating condition, social influence, and performance expectancy had the top three hypothesis [8]

Future recommendation of this research are:

- The results of this study can be developed in further research with coverage for Aconex Systems users from other projects.

- Adding Gender, Age, Experience, and Voluntariness of use for subsequent research

- The results of this study can be developed in further research with other models or approaches that are still relevant to this case

\section{REFERENCES}

[1] GDP Bank of Indonesia (2018)

[2] Dimyati, Hamdan dan Nurjaman Kadar, 2014, Manajemen Proyek : CV Pustaka Setia

[3] Siswantoro, Yuni. (2017) "Persepsi Kemudahan dan Kegunaan Aconex", Jurnal Ilmu Pengetahuan dan Teknologi Komputer, Vol. 2 Februari $2017: 1-13$.

[4] V. Venkatesh, M.G. Morris, G.B. Davis, F.D. Davis, "User acceptance of information technology: toward a unified view, " MIS Quarterly, vol. 27, pp. 425-478, 2003

[5] Maholtra, N. (2010). Marketing Research, 6th Edition

[6] Ghozali, Imam. 2008. Structural Equation Modeling, Metode Alternatif dengan Partial Least Square Edisi 2. Semarang: Badan Penerbit Universitas Diponegoro

[7] Chin, W.W, Marcolin,B.L dan Newsted, P.R.1996. A Partial Least Squares Laten Variabel Modeling Approach for Measuring Interaction Efects: Results From A Monte Carlo Simulation Study And Voice Mail Emotion/Adoption Study. Proceedings Of The Seventeenth International Conference On Information Systems. December 16-18. Cleveland. Ohio.

[8] A.C Obiennu, Amadin F. I. (2016) "Intention to Use University E-mail System based on Modified UTAUT Model: Perspectives of University of Benin Postgraduate Students", Proceedings of the iSteams Multidisciplinary Cross-border conference

[9] Gharaibh Natheer, Gharaibeh Malik, Arshad Muhammad (2018) "Using the UTAUT2 Model to Determine Factors Affecting Adoption of Mobile Banking Services: A Qualitative Approach", International Journal of Interactive MobileTechnology

[10] Nyoman Sedana, Gusti Nyoman, Wijaya Wisnu. (2017) "Penerapan Model UTAUT untuk memahami penerimaan dan penggunaan learning management system" Universitas Sanata Dharma 